\title{
Animal Law in the United Kingdom: Academics, Conferences, A-Law and Student Engagement
}

\section{Simon Brooman ${ }^{1}$ \\ Published online: 27 June 2018 \\ (c) Springer Nature B.V. 2018 \\ Conference on Animal Law, Ethics and Legal Education, Liverpool 2017}

On September 5th 2017, a group of academics, Ph.D. and undergraduate students, and members of several animal welfare charities, gathered together in Liverpool to discuss Animal Law, Ethics and Legal Education. The venue was the School of Law at Liverpool John Moores University where I have been teaching Animal Law since September 1994. Organised in conjunction with the United Kingdom Centre for Animal Law (A-law) and the Liverpool Law Review, it brought to an end several years of pondering whether such a conference would attract enough speakers or delegates. Would there be sufficient interest amongst academics in the United Kingdom to bring a critical mass of research material to the conference room? Was I a member of such a select (i.e. small) band of scholars that a small plate of sandwiches would suffice for lunch? I had some trepidation as to the reaction, or lack of it, I would encounter.

In the event, numbers grew to around 80 delegates from academia and some of the leading charities active in both the United Kingdom and on the global animal welfare stage. Three speakers gave keynote papers to the conference. Mike Radford, reader in Animal Law from the University of Aberdeen led the way with a paper concerning the overall momentum of the development of Animal Law and how the subject has evolved from being one which attracted professional derision, to one that now has a significant impact on government policy regarding animal welfare. He described the conference as one of the most important meetings of animal lawyers and those concerned with animal welfare that had ever taken place in the United

Simon Brooman

S.D.Brooman@ljmu.ac.uk

1 School of Law, Liverpool John Moores University, Redmonds Building, Brownlow Hill, Liverpool L3 5UG, UK 
Kingdom and suggested that it might be a landmark moment in the development of Animal Law amongst academic lawyers alongside those working in the field.

A lack of a critical mass in Animal Law in legal education is something that I have addressed in a recent paper that formed a back-drop for the conference. ${ }^{1}$ I argued that, in contrast to other countries, members of the higher education legal academy have been slow to take up the challenges and opportunities offered by Animal Law. Evidence for this is found in the relatively low number of courses being offered. However, even since this article was published in the Liverpool Law Review in late 2017, I have become aware of new courses in Animal Law (sometimes called Animal Welfare Law or something similar) at Cambridge University and the University of Winchester. These join existing courses at Aberdeen, Liverpool John Moores University and the University of Essex, along with several more. A full updated list of such courses is updated on the A-law website. ${ }^{2}$

A second keynote paper was delivered by Peter Stevenson of Compassion in World Farming. He outlined the considerable challenges being encountered during the Brexit negotiations where CIWF and many other organisations are expending considerable energy in influencing policy development in relation to animals for the post-Brexit era. He outlined particular areas of concern for farm animals including the need to ban live exports of animals, reversing the move to zero-grazing of dairy cows, banning the use of enriched cages (as is the case in Germany), and reducing stock densities in intensive farming. Peter Stevenson's paper was a salutary reminder of the number of areas that will need to be monitored, and possibly challenged, by welfare groups and academics in the post Brexit era. ${ }^{3}$

The final keynote speaker was Chris Butler-Stroud of United Kingdom based Whale and Dolphin Conservation. Chris has a particular connection with the Animal Law course at LJMU having, for a number of years, delivered an annual lecture to undergraduate law students at LJMU in relation to his work on the international protection of cetaceans. These students have often commented how they have felt privileged and inspired by hearing first-hand from Chris about his contribution to preventing the return of industrial whaling to the international arena. Chris discussed his work during his paper and outlined the conflict between the scientific rejection of theories of maximum exploitation, to norms based on the recognition of whales' intrinsic rights. The challenge in influencing the development of animal rights is long-standing in the world of animal welfare. However, Chris' paper indicated that a new acceptance of specific animal rights may be emerging at government policymaking levels to the extent that such a rights based approach has taken its place on the negotiating table. This could be beginning of a new area of scientific and philosophical understanding of animals' sentient qualities, reflected in the emergence of

\footnotetext{
1 Brooman, S. "Creatures, the Academic Lawyer and a Socio-Legal Approach; Introducing Animal Law into the Legal Education Curriculum" (2017) Liverpool Law Review 38: 3, 243.

2 A-law, 2018. Animal Law Courses and Short Modules at https://www.alaw.org.uk/law-courses/.

3 Stevenson, P. "Brexit: Opportunities and Threats for Farm Animal Welfare" (2017) United Kingdom Journal of Animal Law 1: 1, 1-6.
} 
legislation providing for greater species protection according to sentient qualities, not the competing value of animal use as judged by humans.

As well as these three keynote papers, the conference in Liverpool 2018 saw papers delivered by Anne-Marie Brennan, Bridget Martin, Jamie Murray, Gareth Spark, Michael Bowman, Samantha Hurn, Carol Gray, Joe Wills, Debbie Rook, Marie Fox and Sue Westwood, and Darren Calley. In addition, we were able to contrast the development of Animal Law, Ethics and Legal Education with that in the United States through a skype conversation with Kathy Hessler of the Animal Law Clinic Center for Animal Law Studies at Lewis and Clark Law School, Portland, Oregon.

\section{The Future of Animal Law in the United Kingdom}

Where does the development of Animal Law go from here? Amongst legal scholars, Mike Radford is one of the exceptions to the apparent paucity of concern about the relationship between law and animals, having designed and delivered the first ever Animal Law course in the UK in 1992. This was followed by my own (with my friend and colleague, Dr. Debbie Legge), in 1994. As a public lawyer Mike has a particular expertise in the policy aspects of Animal Law. My own particular approach is through the lens of socio-legal studies, the contrasting nature of which shows the variety of approaches that could be taken if more legal scholars entered the Animal Law arena.

Alongside an assumption (and hope) that the current number of interested legal scholars continues to rise, there is a natural focal point in the United Kingdom with the re-emergence of the A-law and its journal the United Kingdom Journal of Animal Law. The work of A-law is best summarised in its own words:

The UK Centre for Animal Law (A-law) is a charity which brings together lawyers and other people interested in animal protection law to share experience and to harness that expertise for the benefit of animals, by securing more comprehensive and effective laws and better enforcement of existing animal protection laws.

In the UK we are unique as an organisation, focusing on promoting knowledge and understanding-both amongst lawyers, universities, animal protection groups and the wider public_about animal protection laws in the UK and elsewhere around the world. We do this through publications, including The UK Journal of Animal Law, training seminars, conferences and online resources and through contributing strategic legal assistance in support of animal protection group projects.

Through our work, we (a) increase the legal capacity of the animal protection community to be better able to use the law to protect animals, and (b) increase the depth of understanding of animal law within the UK legal community, which helps make law and justice in the UK more effective in protecting animals. 
The importance of a central organisation to aid the development of this new widely recognised area of study is immeasurable. The knowledge relating to Animal Law is widely dispersed amongst professionals working in the area, and academics. The part which is now being played by A-law, chaired by Paula Sparks, is to bring these experts together along with an increasing number of research students who themselves are beginning to make a valuable contribution to the development of Animal Law.

The value of A-law is shown very clearly during the current period of Brexit negotiations. At the time of writing (June 2018), there are a number of areas where the post-Brexit replacement arrangements for areas of law and policy covered by membership of the European Union, are in a considerable state of flux. The government's stance in refusing to replace Article 13 of the Treaty on the Functioning of the European Union (TFEU) ${ }^{4}$ which requires public bodies to take account of animal sentience, was met with wide-spread denunciation in November 2017. Welfare experts, Members of Parliament and general public opinion put pressure on the Environment Secretary, Michael Gove, to bring Article 13 into UK law. The collateral public backlash to the Government whipping its own MPs to reject a replacement in English law led to a hastily constructed replacement bill, which itself ran into trouble due to its weak draughtsmanship. ${ }^{5}$ The use of animals in animal experimentation, amongst others, is an area where the post-Brexit arrangement is unclear with experts and welfare groups working together through A-law and the Wildlife and Countryside Link to influence policy. ${ }^{6}$

\section{Creating Opportunities for Student Engagement in Animal Law}

An exciting aspect of the creation of new Animal Law courses, the emergence of an Animal Law conference and the involvement of A-law is the opportunities they provide for student involvement in the development of Animal Law in the United Kingdom. Not only do they affect a change in attitude to animals amongst students, Animal Law courses present opportunities for students to create links with the work of professionals in the area and to develop their awareness of law in the context of external factors. The Animal Law course at LJMU has seen students benefit from work experience in the area although, for a long time, it was difficult to create connections with animal welfare organisations. The emergence of A-law has greatly enhanced this situation as one of its aims is to enhance the links between academia and the work of professionals.

\footnotetext{
4 Treaty of Lisbon Amending the Treaty on European Union and the Treaty Establishing the European Community (2007/C 306/01), Article 13.

5 Brooman, S. "Animal Sentience in UK law: does the new clause need claws?" (2018) United Kingdom Journal of Animal Law, forthcoming.

6 Sparks, P., and S. Brooman. "Brexit: A New Dawn for Animals Used in Research, or a Threat to the 'Most Stringent Regulatory System in the World?" (2018) United Kingdom Journal of Animal Law 1 (2), 1.
} 
A-law student groups have emerged at universities including LJMU. This enables students to explore the nature of working for animal welfare organisations from those in the field. Law students at LJMU also made their own submission to the government's consultation on fur-farming in early 2018 having met to consider their thoughts. This followed an assignment on their Animal Law module linked to furfarming that enabled them to gain awareness of the area so creating a direct link between their academic work and the on-going development of government policy. This is a good example of how A-law's involvement is crucial as it provides the focal point for academics, students and professionals.

The future of the conference is likely to provide further opportunities for students in addition to the existing national Animal Law student essay competition run by A-law. The Liverpool conference in 2107 saw three LJMU students from the Animal Law course, Heather Dooley, Alex Nolan-Webster and Lauren Sas, present a paper on the effects of studying Animal Law in terms of their greater appreciation of sustainability and the personal impact of discovering more about animal welfare. One of their main comments was that they would have liked to have studied more of Animal Law.

Subsequent to the conference the involvement of students has been explored by the A-law Student Group during a meeting in June 2018. We would like to see more student groups lead by A-law Student Ambassadors in universities across the UK. They will be provided with support and resources to raise the profile of Animal Law, maintaining a law focus but welcoming the involvement of students from other discipline areas. The Animal Justice UK journal is a sister journal of the UK Journal of Animal Law and has a greater focus on the A-law student community. It provides an opportunity for students to publish peer reviewed articles and updates on the activities of their respective university groups. A-law is continuing to develop resources and links to help students studying Animal Law, academics setting up or running existing courses and for those working to influence policy and law in NGOs. The emphasis through these new developments is that students should be at the heart of developing the discipline of Animal Law and influencing policy to ensure that animals are given greater protection in UK law. This kind of partnership work has been recognised as being particularly important in the future development of higher education.

\section{The Animal Law Articles Presented Here}

The continuing and increasing role of academics in the development of Animal Law is obviously vital. Academics complete the work of professionals in the area, the development of public policy and laws, and the engagement of students. It is surprising that more legal academics have not taken up the subject in the UK-although there is evidence from development of new courses that we might finally begin to

\footnotetext{
7 Healey, M., Flint, A., and K. Harrington. "Engagement through partnership: students as partners in learning and teaching in higher education" (2014) Higher Education Academy.
} 
catch up the exponential increase in provision elsewhere in the world. The period between 1999 and 2014 saw the development of 150 Animal Law courses in the United States, whilst UK saw perhaps one or two-this is one of the more remarkable statistics in the emergence of the subject, especially as the UK has such a renowned record in the historical development of animal welfare legislation. ${ }^{8}$

However, the articles in this edition of the Liverpool Law Review show the level of scholarly activity that can be achieved in Animal Law, and from different perspectives. The first three are the result of papers presented at the 2017 conference in Liverpool.

Jamie Murray's article places animals in the dialogue between law and ecology and is important because it addresses the theoretical positioning of Animal Law. This is a central consideration for the subject as it develops the identity of Animal Law and ensures that it is not merely seen as the junior brother of environmental law. It is my contention, and of many others, that Animal Law is deserving of recognition as a separate area of study because of its unique connection with and responsibilities created towards sentient creatures. In Animal Law, sentient creatures are not the objects to be transferred or disposed of, but the creatures deserving of protection in their own right. Murray's article suggests that the place of the animal has already be reserved in emerging conversations around the development of law and ecology and it can make a substantial contribution in that area.

Debbie Rook examines an area of law that touches on the very essence of the relationship between humans and non-human animals - that of companion animals. Animal law is not all about Brexit, although it may appear to be so in recent times. The law relating to animals can touch on the lives of human and non-human animals in a much more personal way. It is well-known and documented that humans often build relationships with animals that match those with other humans in terms of their importance to the individuals concerned. Humans, and non-human animals share the capacity to grieve for loss or suffer through being kept apart. Often, a companion animal is all that is left for someone who has suffered bereavement or simply failed to build relationships elsewhere. What happens if the application of law, in this case housing law, disrupts the relationship between the species as a companion animal is not welcome in the accommodation concerned? How can we reconcile the conflict of what suits landowners and is enforceable in law, as opposed to what may be an essential companion animal relationship, possibly with implications for mental health?

Carol Gray investigates another factor of this complex human-non human relationship in terms of the decision making powers that humans have over their animals. The concept of an animal being owned is sometimes problematic in philosophical terms as the desires of humans may not match what is appropriate for the animals concerned. An obvious example is the decision over the use land which may be of benefit for humans, usually through financial gain, as opposed to what is of benefit for animals who use the land. In a similar vein, Gray examines when it is desirable that veterinary professionals intervene to protect the rights of the animal. Should the rights of the owner always

\footnotetext{
${ }^{8}$ Brooman, S., supra n. 2, p. 244.
} 
be paramount or should there limits to this traditional power held by owners over their pets?

In the fourth article Laura Donnellan takes us back to the vital area of the European Union's role in developing measures to protect animal welfare. Using the regulation of cat and dog fur as an example, Donnellan unpicks one of the key issues that has been raised around the EU's protection of animals. Despite the presence of legislation to protect animals, does the EU always adequately enforce it? It has sometimes been said that the EU is inconsistent in its approach to animal welfare. It has been the originator of many laws that have brought protection for animal to parts of the EU that were previously unprotected. The use of animals in agriculture and experiments are two notable examples. However, other areas such as religious slaughter and the production of animals for fur have managed to escape significant control because of the cultural and financial value placed on such use of animals. ${ }^{9}$ The use of animals in fur production continues in the EU despite evidence that it severely compromises the mental health of essentially wild animals. Religious slaughter continues despite evidence of severe suffering for animals around the time of cutting if anaesthetic is not employed. How does the regulation of cat and dog fur compare to these other practices? Is it a success story for the regulation of animal suffering and welfare in the EU, or is it another case of EU regulation without teeth?

Overall, the four articles presented here provide a snapshot of what is possible if more legal academics were to rise to the challenge of contributing to the development, scope and identity of Animal Law. There are not many times in the life of a legal academic when a there is a genuine opportunity to research and teach a new area of law, especially one that has a cross-disciplinary attraction through its connections with science, history and philosophy. When did academic lawyers become so enwrapped in the doctrinal development of existing law that they failed to notice the emergence of an area of law relating to other species that, dare I say, has links with what appears on many plates (as a vegan, not my own), walks down the hall to greet us and dies in the production of our medicines? More importantly, why did we ignore the important philosophical imperatives to provide justice for animals who exist in their own right? Perhaps it is time that the legal academy woke up, looked at the law, and smelled the manure.

Acknowledgements Thanks to Gary Wilson, Editor of the Liverpool Law Review, for his help and support in the publication of this special edition on Animal Law; Paula Sparks, Chairperson of A-law who works tirelessly to ensure that academics, professionals in the area of animal welfare, researchers and students work together to influence policy and provided invaluable advice and support in arranging the conference; Darren Calley and Gareth Spark for their help in the production of this special edition and chairing sessions during the conference and; colleagues at LJMU, Lorie Charlesworth, Jim Hollinshead, Nirmala Pillay and Alex Pimor who chaired sessions at the conference and ensured that the feedback was so positive.

\footnotetext{
9 Brooman, S. 2016. "In Search of the Missing Ingredient: Religious Slaughter, Incremental Failure and the Quest for the Right to Know." (2018) Journal of Animal Ethics, 6: 2, 153-63; Brooman, S. "Politics, Law and Grasping the Evidence in Fur Farming: A Tale of Three Continents" (2018) Journal of Animal Ethics, forthcoming.
} 